\title{
乌东德水电站下白滩砂石加工系统工程环保工程设计与实施效果 分析
}

罗文起 张斌

中国水利水电第七工程局有限公司第五分局

DOI:10.32629/hwr.v4i1.2707

[摘 要] 简述了乌东德水电站下白滩砂石加工系统工程工艺流程和和环保工程设计,总结了粉尘、噪声和废水污染治理的设计和实施情况,分 析了环保工程实施效果,探索了人工砂石系统环保工程的优化工艺。实现节能减排,防治污染,绿色环保目的目标。

[关键词] 砂石加工系统; 环保工程; 设计；实施；效果分析

\section{1 工程概述}

乌东德水电站位于云南省禄劝县和四川省会东县交界的金沙江下游 河道上, 电站装机总容量1020万千瓦, 装机规模中国第四、世界第七。乌东 德水电站下白滩砂石骨料加工系统工程主要承担电站左右岸地下厂房、导 流洞、泄洪洞等分项工程 450.5 万的混凝土所需粗、细骨料生产任务。其 中预冷混凝土约 320.2 万 $\mathrm{m}^{3}$, 碾压混凝土约 55.3 万 $\mathrm{m}^{3}$ 。二级配混凝土量约占 $73.1 \%$, 三级配混凝土量约占 $26.9 \%$ 。砂石骨料加工系统由粗碎车间、半成 品堆场、第一篮分车间、中细碎车间、第二篮分车间、第三篮分车间、超 细碎车间、小石冲洗车间、棒磨机车间、成品料堆场、成品料装车仓、供 水系统和废水处理系统组成。该系统于2013年4月建成投产, 2019年9月生 产运行结束。

\section{2 系统生产工艺流程及布置 \\ 2.1系统生产工艺流程 \\ 乌东德水电站下白滩砂石加工系统工艺流程图见图1。 \\ 2. 2 系统生产工艺流程简述}

(1) 乌东德水电站下白滩砂石加工系统工程采取 “两段破碎、立轴破 与棒磨机联合制砂” 及 “半湿半干” 的人工制砂破碎流程。粗碎车间与棒 磨机车间开路生产; 一篮车间、中细碎车间、二篮车间、三篮车间及超细 碎车间既可以闭路循环生产, 又可以开路生产; 各生产车间用胶带输送机 相连接。

(2) 系统加工砂石骨料的料源以灰岩为主。根据料源的岩石特性和粗 细骨料生产强度及质量要求, 采用绿色环保半湿半干制砂工艺进行系统生 产流程设计。

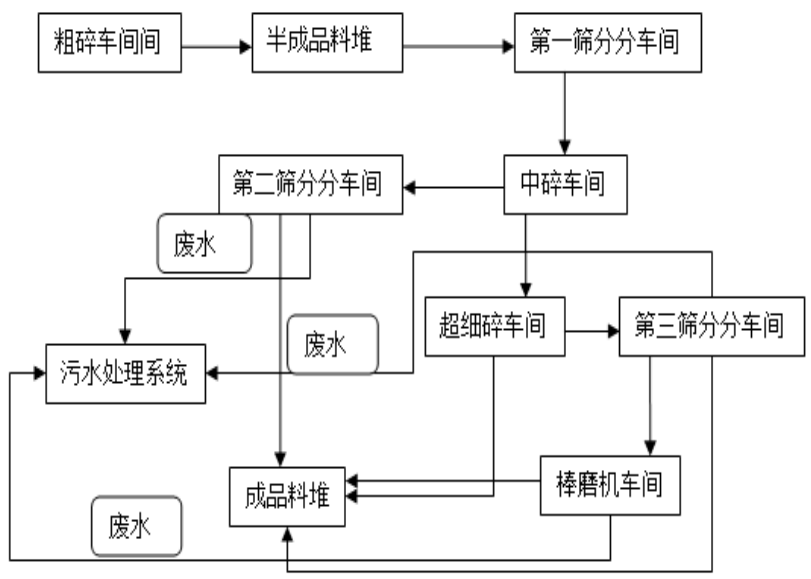

图1 下白滩生产工艺流程图

\section{3 环保工程设计理念及实施目标}

乌东德水电站下白滩砂石加工系统工程按照 “建设绿色粮仓、助力绿 色发展” 的理念进行环保工程设计。全面落实环境保护和水土保持各项工 作, 保护和改善作业现场的环境, 控制现场的各种粉尘、废水、废气、固体 废弃物、噪声、振动等对环境的污染和危害。依据合同文件环保工程实施 目标如下:

(1) 废水回收率不低于为 $70 \%$, 处理后水质 $\mathrm{SS} \leqslant 70 \mathrm{mg} / \mathrm{L}$, 水质指标 SS指 标执行《污水综合排放标准》(GB8978-1996) 达到一级排放标准, 处理后的 废水回收循环利用于生产節分, 不外排。

(2) 空气中有害物质最高允许浓度为: 含有 $10 \%$ 以上游离二氧化硅的粉 尘 (石英岩等) 最高允许浓度为 $20 \mathrm{mg} / \mathrm{m}^{3}$, 游离二氧化硅含量在 $10 \%$ 以下的粉 尘 (石英岩等) 最高允许浓度为 $10 \mathrm{mg} / \mathrm{m}^{3}$, 其粉尘排放应符合国家颁布的 GB3095的有关规定。

(3) 采取适当措施降低或减少各生产车间的噪音, 各主要生产车间应 设置隔音控制室。

\section{4 环保工程设计及实施效果分析}

4. 1 废水处理系统情况

4.1. 1 废水处理工艺流设计

下白滩砂石加工系统成品骨料生产能力为 $1000 \mathrm{t} / \mathrm{h}$ 。砂石系统需水量 为 $920 \mathrm{~m}^{3} / \mathrm{h}$, 补充水量 $\geqslant 300 \mathrm{~m}^{3} / \mathrm{h}$, 废水处理量为 $810 \mathrm{~m}^{3} / \mathrm{h}$ 。废水处理采用 “机 械预处理” + “辐流沉淀池 (加药) ” “ “机械压滤脱水” 的比较先进生产工 艺。废水回收率不低于为 $70 \%$, 处理后水质 $\mathrm{SS} \leqslant 70 \mathrm{mg} / \mathrm{L}$ 。生产废水经处理后 回收循环利用, 作为生产篮分用水, 无外排。废水处理工艺流程见图2。

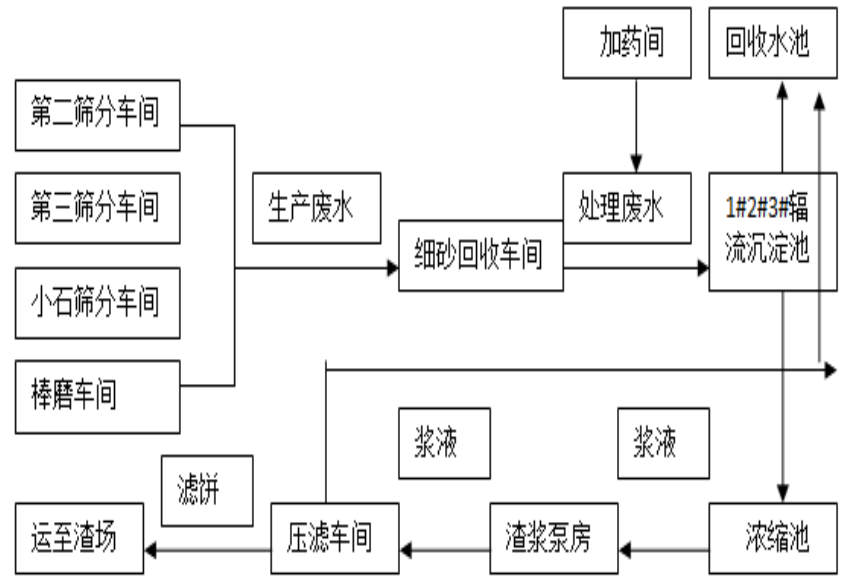

图2 下白滩废水处理流程图 
系统工程生产废水主要产生于第二笁分车间、第三笁分车间、小石冲 洗车间及棒磨机车间, 四个车间废水汇流后自流到细砂 (石粉) 回收车间, 经克莱伯斯 (VDS512-4) 细砂 (石粉) 回收装置将废水中粒径 $\geqslant 0.035$ 的细砂 回收, 该处回收细砂 (石粉) 约为 $38 \mathrm{t} / \mathrm{h}$, 细砂及石粉即可参入成品砂中, 也 可作为弃料运走。辐流沉淀池由泥浆区、沉淀区和清水区构成, 机械预处 理后的废水通过管道自流到配水井, 由配水井将废水分配到三座 $\Phi 25 \mathrm{~m}$ 辐 流沉淀池; 采用渡槽周边供水方式, 停留 $3^{\sim} 4 \mathrm{~h}$, 沉淀区加药加速沉淀, 清水 区清水采用周边出水方式经溢流槽汇流到排水管流至回收水池暂存。泥浆 区泥浆用周边刮泥机刮入浓缩池, 用渣浆百抽至机械压滤车间经箱板式高 效快速压滤机将泥浆干化形成滤饼, 滤饼放入自卸汽车运输至业主指定渣 场有序堆放。经压滤机处理后的清水自流到回收水池。回收水池的水由回 收水洜抽到调高程为 $1015 \mathrm{~m}$ 高位水池。废水处理后回收循环利用于系统生 产运行, 无外排。

4. 1.2 废水处理实施效果分析

(1) 生产废水循环利用率实际达 $72 \%$ 以上, 实际水处理能力达 $870 \mathrm{~m}^{3} / \mathrm{h}$ 。 系统三座辐流沉淀池和 4 台压滤机分别循环使用, 可连续生产运行, 极大缩 短了运行时间。

(2) 实现零污染排放目标。处理后水质 SS $\leqslant 70 \mathrm{mg} / \mathrm{L}$, 循环利用于生产筛 分, 无外排。泥砂经压滤机进行固液分离后形成滤饼, 放入自卸汽车运输至 渣场有序堆放, 能实现零污染排放。

(3) 细砂 (石粉) 回收效果好。石粉回收装置能将生产废水中粒径？ 0.035 的颗粒脱水分离出来, 根据需要掺加于人工砂中, 回收细砂 (石粉) 量 约为 $38 \mathrm{t} / \mathrm{h}$, 提高了成品砂产量和质量, 同时对细度模数和石粉含量都有较 大改善, 极大地改善了碾压混凝土性能。

(4) 取得良好的经济效益和社会效益。经统计; 生产废水处理于 2013 年3月建成并投入试运行, 截止 2014 年 10 月 20 日, 累计用水量 309.4 万 $\mathrm{t}$, 处 理生产废水及回收循环利用量 221.3 万t, 回利用率达 $72 \%$ 以上, 污泥处理量 为 57.8 万t, 不但节约了生产运行成本, 也创造了社会和环保效益。

4. 2 噪声污染防治情况

系统粗碎车间、中细碎车间、第二篮分车间、第三笁分车间及J2胶带 机机腰传动位置用隔音板对四周进行封闭修建隔音罩降噪。第一篮分车间 及棒磨机车间在上游侧用隔音板修建隔音墙进行降噪。破碎机及篮分机座 子均采用橡胶墩进行减振降噪; 篮分机均采用聚氨脂篮网、各下料斗及溜 槽采用废胶带进行铺设以减小碎石撞击声进行降噪。各个料堆尽量将料堆 高以减小碎石下落高度来进行降噪。各生产车间设置值班室, 施工人员均 配有耳塞进行降噪。

采取上述措施后, 项目部每年委托有资质的第三方对生产场所生产运 行期间职业健康危害因素进行检测; 业主每季度委托有资质的单位对砂石 系统噪声、粉尘、废水进行检测。经检测, 各项指标均满足《工业企业噪 音卫生标准》规定。

4. 3砂石骨料加工系统粉尘防治情况

4. 3. 1 砂石骨料加工系统防尘设计
4.3.1.1粗碎车间防尘设计

粗碎车间破碎设备采用3台鄂式破碎机, 生产过程中会产生大量粉尘, 特别是在自卸汽车卸料及开机时粉尘最大, 主要采取如下几种措施：(1) 从料源上控制石料, 含泥量高不合格石料禁止进入粗碎受料坑; (2) 自卸汽 车卸料前, 在粗碎车间卸料平台修建喷水棚对毛料喷水, 以减少或消除卸 料时扬尘; (3) 在受料坑上方设置喷水设施和雾炮机, 以减小生产过程中扬 尘; (4) 利用粗碎车间四周隔声罩封闭降尘, 防止扬尘; (5) 在胶带输送机 下料点安装喷淋装置, 以减小胶带输送机运输过程中扬尘。

4. 3. 1. 2成料骨料加工及堆存车间防尘

系统主要扬尘点为第二、三笚分车间和超细碎车间。根据车间布置情 况和扬尘特点, 主要采取如下措施来降低扬尘。

(1) 采用半湿半干式生产工艺技术, 小石笚分车间为湿法生产, 其余篮 分车间半湿半干式生产, 灵活控制半成品含水率, 使料流在整个输送过程 处于最佳含水状态, 可有效减小骨料在加工和运输过程中的扬尘; (2) 中细 碎车间、第二、三篮分车间利用四周隔声罩封闭降尘; (3) 棒磨机车间为 湿法制砂, 在中细碎和超细碎上方和各胶带输送机上安装喷淋设施, 在各 间调节料堆粉尘较大处增设雾炮机喷雾以减少扬尘; (4) 对系统内道路和 所有地坪进行硬化, 安排专人对场地进行卫生清理和酒水, 减少道路和地 面扬尘; (5) 对场地裸露地块进行种树、种花、种草, 搞好绿化工作, 减少 和降低空气中的尘埃, 并定期对花草树木喷水洗尘, 以净化空气。

4. 3. 1. 砂石骨料加工系统防尘效果

下白滩砂石骨料加工系统生产运行过程中, 项目部每年委托有资质的 第三方对生产场所生产运行期间职业健康危害因素进行检测; 业主每季度 委托有资质的单位对砂石系统噪声、粉尘、废水进行检测, 经检测, 各项指 标均满足法律、法规、标准、合同的规定。

\section{5 结语}

乌东德水电站下白滩砂石骨料加工系统工程, 针对生产运行过程中生 产废水、噪声、粉尘等主要污染源情况, 承包人秉持着 “建设绿色粮仓、 助力绿色发展” 的理念, 设计和实施了节能、节材、节地、节水和施工环 保, 并在实施过程中不断创新和完善, 实现合同约定的各项环保指标, 既创 造良好的经济效益, 又创造了良好的环保和社会效益, 环保经验值得进一 步总结和推广。

[参考文献]

[1]罗小涛.李亚军阿尔塔什水利枢纽面板堆石坝面板混凝土施工技 术[J]工程建设与设计,2019(15):228-230+240.

[2]李万里.关于生态型水环境治理技术的分析与研究[J]工程建设与 设计,2019(18):146-147+150.

[3]李浩然.对于水电站砂石加工废水处理工艺现有问题的探讨 [J]微 量元素与健康研究,2010(4):70.

作者简介:

罗文起(1975--), 男, 贵州六枝人, 汉族, 本科, 高级工程师, 长期从事 水利水电工程施工管理工作。 